\title{
Improving The Quality of Science Learning Through Mind Mapping Model with Flashcard
}

\author{
Herwinta Inggil Rejeki ${ }^{1}$, Rosti Hidayah ${ }^{2}$, Lena Cendrawati ${ }^{3}$, Juwarti $^{4}$ \\ ${ }^{1,2,3,4}$ Faculty of Education, Universitas Negeri Semarang, Indonesia \\ Corresponding email: inggil.rejeki@yahoo.com
}

\begin{abstract}
The results indicate that teachers have not developed creative thinking skills of students in science learning so that the average daily students' test scores could not achieve the specified passing standard. To overcome the problems appli cation of mind-mapping model with flashcard was applied. The purpose of this research was to improve teacher skills, students' activity, and students' learning result. Classroom action research was conducted in two cycles. Every cycle consisted of two meetings, with the stages of planning, action, observation, and reflection. The subjects of the research were teachers and 33 students of class V(A) SD N Sampangan 01, Semarang. The data were collected by using tests and non-test. The results of the research show that: (1) the average of teacher skills in the first cycle scored 20 with enough category and increased in the second cycle to 28.5 with a very good category; (2) the average of students activity in the first cycle was 16.31 with enough category and increased in the second cycle to 25.42 in good category; (3) students' learning results in the first cycle achieved mastery of $75.76 \%$ and increased in the second cycle to $84.85 \%$. The conclusion of the research was that mind-mapping model with flashcard improved the teacher skills, students' activity, and students' learning results in science learning to V(A) class SDN Sampangan 01, Semarang.
\end{abstract}

Keywords: flashcard, quality of science learning, mind mapping

\section{Introduction}

The paradigm shift of teaching becomes the paradigm of learning in the world of education today affecting improvement of students' creative thinking ability. Learning paradigm that focuses more on the role of students in the learning process gives a positive impact on the students because students can develop all the potential and creativity. Law Number 20 Year 2003 Article 4 paragraph (4) on the National Education System asserts that education is organized by giving exemplary, building willingness, and developing the creativity of learners in the learning process . Natural Science (IPA) refers to human efforts to understand the universe through observations of the right (correct) at the target, using the correct procedure (true), and is described with reasoning (valid) so that the resulted conclusions are correct (truth). The quality of science learning in Indonesia is still considered low. This is shown by the results of international studies conducted by Program International Student Assessment (PISA) in 2012, published by the Organization for Economic Cooperation and Development (OECD). The study was attended by 34 OECD member countries and 31 partner countries (including Indonesia). The results showed that Indonesia was in the 64th rank out of 65 countries participating in the test. The average gained score for science only reached 382. In fact, the average OECD score for science is 501 .

Researchers then did reflection about the quality of science learning, in this case, in terms of V(A) class students in SDN Sampangan 01 Kota Semarang. The results of reflection indicated that science learning implemented in the VA class has not reached the goal of science learning optimally.

It was also supported by the results of science learning evaluation on VA class students in SDN Sampangan 01 Semarang on science lesson of academic year 2013/2014 in the first semesterwhich has not fulfilled the Minimum Exemption Criteria (KKM) of the school that is 60 . Based on the data obtained from 33 students, only 13 students $(39.40 \%)$ whose average daily test scores were able to fulfill the KKM and the remaining 20 students $(60.60 \%)$, the average daily test score can not reach the determined KKM. Science learning in class VA in SDN Sampangan 01 Semarang require an improvement for learning by applying the model and learning media for science which is effective, creative, innovative, and fun so as to improve the quality of learning that includes the skills of teachers, student activities, and learning outcomes. Researchers with in collaboration 
implemented science learning with innovative learning models and media to overcome the problems that occur in the classroom of SD SD Sampangan 01 Kota Semarang through the model Mind-

Mapping with Flashcard media .

Buzan (2005) explains "Mind Map ping it's a creative and effective means of note taking that litterally "maps out" your thoughts ". Mind Map ping is a creative, effective, and literally creative way to "map" our thoughts. DePorter and Hernacki (2013) also explain that the Mind Map ping is able to create a mental connection that helps students to understand and remember.

Learning media that can support the model of Mind Map ping in the process of learning sains is Flashcard. Excess Flashcard media : (1) easy to carry everywhere because of its size the size ofpostcard; (2) practically in making and using it, so when any student can learn well using this medium; (3) easy to remember because this card is very interesting, contains letters or numbers, simple, stimulate the brain longer remember the message on the card; and (4) is very fun to use as a medium of learning, in the form of games (Indriana, 2011).

\section{Methods}

This research is a classroom action research consisting of 2 cycles. Each cycle consisted of 2 meetings. The research subjects consisted of teachers and students. Observations for student activity involved 33students in the class of SD Sampangan 01 Kota Semarang. The implementation of this research referred to the research model that proposed by Kemmis and Taggart (Arikunto, 2006). Each cycle or cycle of action included planning, action execution, observation, and reflection.

The data collection techniques employed test and non-test techniques. The type of data in this research was quantitative and qualitative data. Quantitative data in the study was analyzed by using descriptive analysis technique by determining mean or mean, maximum score, and minimum score. While the qualitative data was analyzed by using qualitative descriptive analysis.

\section{Results and Discussion}

\subsection{Master's Skills}

Improving teacher skill in science learning can be seen in table 1 below.

Table 1. Improving Master's Skills

\begin{tabular}{|c|c|c|c|}
\hline \multirow{2}{*}{ No } & \multirow{2}{*}{ Teacher Skills Indicators } & \multicolumn{2}{|c|}{ Score } \\
\hline & & Cycle I & Cycle II \\
\hline 1. & $\begin{array}{l}\text { Carry out preliminary activities using Mind } \\
\text { Mapping model withFlashcard media }\end{array}$ & 2.5 & 3.5 \\
\hline 2. & $\begin{array}{l}\text { Provides questions about the displayed Flashcard along with the } \\
\text { outline of the material }\end{array}$ & 2.5 & 3.5 \\
\hline 3. & $\begin{array}{l}\text { Describes the material using Flashcards and how to create Mind } \\
\text { Mapping }\end{array}$ & 3 & 4 \\
\hline 4 & Guiding group formation & 2.5 & 3.5 \\
\hline 5. & Guiding students in making Mind Mapping & 2.5 & 3.5 \\
\hline 6. & $\begin{array}{l}\text { To guide the presentation of the result of group discussion on Mind } \\
\text { Mapping that has been made }\end{array}$ & 2 & 3 \\
\hline 7. & Give appreciation to the best group. & 2.5 & 4 \\
\hline & Closes lessons by summarizing material and providing evaluation & 2.5 & 3.5 \\
\hline $\mathrm{Nu}$ & ber of scores gained & 20 & 28.5 \\
\hline Av & cage score & 2.50 & 3.56 \\
\hline Per & entage & $62.50 \%$ & $89.06 \%$ \\
\hline Cat & gory & Good & Very good \\
\hline
\end{tabular}

Information: $8 \leq$ score $<13.5$ (Less), $13.5 \leq$ score $<20$ (Enough), $20 \leq$ score $<26.5$ (Good), $26.5 \leq$ score $\leq 32$ (Very good)

Based on Table 1 and Figure 1, the skills of teachers have improved from cycle I to cycle
II. In cycle I the score reached 20 with good category, then increased to 28.5 with very good 
category. It shows that teachers can master the eight basic skills of teaching teachers and also determined success indicator has also been achieved that is at least good with a minimum score of 20. Basic teaching skills (teaching skills ) is a form of behavior that is fundamental and specific that must be owned by a teacher as initial capital to carry out their learning tasks planned and professional. The eight basicskills of teaching teachers are as follows: (1) skills for opening and closing lessons (2) questioning skills (3) empowering skills (4) skill in performing variations (5) explaining skills ; (6) skills to guide small group discussions; (7) classroom management skills ; and (8) individual learning skills (Sutikno, 2013).

\subsection{Student Activity}

Increased student

activity on science learning can be seen in table 2 below.

Table 2. Enhancement of Student Activity

\begin{tabular}{|c|c|c|c|}
\hline \multirow[b]{2}{*}{ No. } & \multirow{2}{*}{ Student Activity Indicators } & \multicolumn{2}{|c|}{ Earned Scores } \\
\hline & & Cycle I & Cycle II \\
\hline 1. & $\begin{array}{l}\text { Follow the preliminary activities using Mind } \\
\text { Mapping model withFlashcard media }\end{array}$ & 1.85 & 3.23 \\
\hline 2. & $\begin{array}{l}\text { Answer the teacher's question about Flashcard displayed along } \\
\text { with the outline of the material }\end{array}$ & 1.90 & 3.11 \\
\hline 3. & $\begin{array}{l}\text { Pay attention to teacher's explanation on how to create Mind } \\
\text { Mapping }\end{array}$ & 1.85 & 3.11 \\
\hline 4 & Order moment formation group & 1.94 & 3.11 \\
\hline 5. & Create Mind Mapping as instructed by the teacher & 2.41 & 3.56 \\
\hline 6. & $\begin{array}{l}\text { Present the results of the group discussion on Mind Mapping that } \\
\text { has been made }\end{array}$ & 1.94 & 2.91 \\
\hline 7. & Doing questions about Mind Mapping created by other groups & 2.08 & 3.17 \\
\hline & $\begin{array}{l}\text { Together the teacher formulates the material conclusions and does } \\
\text { the evaluation }\end{array}$ & 2.35 & 3.25 \\
\hline Aver & age Score Count & 16.31 & 25.42 \\
\hline Aver & age Score & 2.04 & 3.18 \\
\hline Perc & entage & $50.95 \%$ & $\mathbf{7 9 . 4 4 \%}$ \\
\hline Cate & gory & Enough & Good \\
\hline
\end{tabular}

Information: $8 \leq$ score $<13.5$ (Less), $13.5 \leq$ score $<20$ (Enough),

$20 \leq$ score $<26.5$ (Good), $26.5 \leq$ score $\leq 32$ (Very good)

In accordance with Table 2, the increase in the observation of student activity first cycle and the first cycle I will be presented in Figure 2 below.

Based on Table 2 and Figure 2, student activity has increased from cycle I to cycle II. This increase occurs after using the Mind Mapping model with Flashcard media on science learning in accordance with the steps of classroom action research. The increase of student activity score score in cycle I only reached 16.31 with percentage $50.95 \%$, so that included enough category. Obtaining score of student activity on implementation of action of cycle II increased reach score 25.42 with percentage $79.44 \%$, so that including good category. Student activity indicators are observed in accordance with the learning steps of the Mind

Mapping model with Flashcard media that has been adapted to student activity in learning. According to Diedrich ( in Spirituality, 2010 ) student activity in learning includes visual activities, oral activities, listening activities, writing activities, drawing activities, motor activities, mental activities, and emotional activities.

\subsection{Student learning outcomes}

The improvement of students' learning outcomes in science learning can be seen in Table 3 below. 
Table 3 Improving Student Learning Outcomes

\begin{tabular}{|c|c|c|c|}
\hline \multirow[b]{2}{*}{ No. } & \multirow{2}{*}{ Information } & \multicolumn{2}{|c|}{ Earned Scores } \\
\hline & & Cycle I & Cycle II \\
\hline 1. & Average grade value & 64.92 & 78.33 \\
\hline 2. & The highest score & 82.50 & 97,50 \\
\hline 3. & The lowest value & 37.50 & 42.50 \\
\hline 4 & Number of students completed & 25 & 28 \\
\hline 5. & $\begin{array}{l}\text { The number of students is not } \\
\text { complete }\end{array}$ & 8 & 5 \\
\hline 6. & Completion of Classical Learning & $75.76 \%$ & $84.85 \%$ \\
\hline
\end{tabular}

In accordance

3 , improvements in student outcomes in cycle I and cycle II will be presented in Fig 3 and 4 below.

Diagram percentage mastery of student learning outcomes in cycle I showed that students' classical learning completeness equal to $75.76 \%$ with average class reach 64,92 . Students complete as many as 25 students and students who do not complete as many as 8 students. The highest score obtained by students is 82.50 , while the lowest score obtained by students is 37.50 . Diagram percentage mastery of student learning outcomes in cycle II shows that students learning classical completeness of $84.85 \%$ with the average class reached 78.33. Students who complete as many as 28 students and students who do not complete as many as 5 students. The highest score obtained by students is 97.50 , while the lowest score obtained by students is 42.50 .

\section{Conclusion}

Based on the results of research that has been held, it can be concluded that applying learning through the

MindMapping model with Flashcard media can improve teachers' skills, students' activities, and students' learning outcomes of class V(A) SDN Sampangan 01 Semarang in learning science.

\section{Reference}

Arikunto,

Suharsimi. (2006). Research procedure. Jakarta: Rineka Cipta.

Buzan, Tony. (2005). The Ultimate Book of Mind Maps. London: Thorsons.

DePorter, Bobbi \& Mike Hernacki. (2013). Quantum

Learning, trans. Alwiyah

Abdurrahman . Bandung: Kaifa Learning.

Indriana, Dina. (2011). Variety of Teaching Media Aids. Yogyakarta: DIVA Press.

Rohani, Ahmad. (2010). Teaching Management (An Introduction Towards Professional Teachers). Jakarta: Rineka Cipta.

Sutikno, M.Sobry. (2013). Learning and Learning Creative Efforts in Achieving Successful Learning. Lombok: Hollistica. 